\title{
PENGARUH PEMBIAYAAN BERDASARKAN JENIS PENGGUNAAN TERHADAP NON PERFORMING FINANCING PADA BANK UMUM SYARIAH (BUS) DAN UNIT USAHA SYARIAH (UUS) DI INDONESIA PERIODE JANUARI 2009 - DESEMBER 2015'
}

\author{
Diah Ayu Legowati \\ Program Studi S1 Ekonomi Islam-Fakultas Ekonomi dan Bisnis-Universitas Airlangga \\ Email : ayuudiahh@gmail.com \\ Ari Prasetyo \\ Departemen Ekonomi Syariah-Fakultas Ekonomi dan Bisnis-Universitas Airlangga \\ Email : ari_feunair@yahoo.co.id
}

\begin{abstract}
:
The purpose of this research was to analyze the impact of working capital financing, investment financing and consumption financing on Non Performing Financing of Islamic Banking Industry in Indonesia from January 2009 until December 2015. This research using a quantitative methods. The data used are the secondary data from Financial Services Authority official website. The analytical methods used in this research is the method of multiple linear regression with a significance level of 0,05. Based on the analysis, working capital financing and investment financing partially provide a significant impact on the ratio of non performing financing. Only consumption did not significantly affect the ratio of non performing financing. However, working capital financing, investment financing and consumption financing are simultaneously provide a significant impact on the ratio of non performing financing.
\end{abstract}

Keywords: Non Performing Financing, Working Capital Financing, Investmen Financing, Consumption Financing

\section{PENDAHULUAN}

Islam merupakan agama yang Indonesia sebagai negara bersifat paripurna dan universal. Juga merupakan agama yang lengkap dalam memberikan tuntunan dan panduan bagi kehidupan umat manusia (Huda, 2010:1). Kesejahteraan hidup umat di muka bumi ini dapat diwujudkan dengan melakukan kegiatan ekonomi. Menurut Antonio (2001:15) sistem ekonomi yang dikembangkan oleh Islam memiliki tujuan untuk mewujudkan tingkat pertumbuhan ekonomi umat manusia dalam jangka panjang dan memaksimalkan tingkat kesejahteraan umat manusia. Kesejahteraan dalam pandangan Islam bukan hanya dinilai dengan ukuran material saja, tetapi juga dinilai dengan ukuran non material.

1] Jurnal ini merupakan bagian dari skripsi yang ditulis oleh Diah Ayu Legowati; NIM: 041211431030 diuji pada 3 Juni 2016 
Legowati, et al/Jurnal Ekonomi Syariah Teori dan Terapan Vol. 3 No. 12 Desember 2016: 1006-1019; PENGARUH PEMBIAYAAN BERDASARKAN JENIS PENGGUNAAN TERHADAP NON PERFORMING FINANCING PADA BANK UMUM SYARIAH (BUS) DAN UNIT USAHA SYARIAH (UUS) DI INDONESIA PERIODE JANUARI 2009 - DESEMBER 2015

Data dari Statistik Perbankan Syariah yang dicatat oleh Otoritas Jasa Keuangan setiap tahun menunjukan bahwa aset milik bank syariah mengalami kenaikan diiringi dengan peningkatan jumlah bank dan kantor yang tersebar di Indonesia. Seiring dengan semakin meningkatnya jumlah bank syariah di Indonesia, menunjukkan meningkatnya kepercayaan masyarakat terhadap sistem perbankan syariah

Sebagaimana halnya sama dengan bank konvensional, bank syariah juga mempunyai peran sebagai lembaga perantara (intermediary) antara satuansatuan kelompok masyarakat atau unitunit ekonomi yang mengalami kelebihan dana (surplus unit) dan kekurangan dana (deficit unit) (Arifin, 2002:49). Menjalankan perananya selaku lembaga perantara kevangan artinya menjalankan dua fungsi utama bank yaitu menghimpun dana masyarakat dan memberikan kredit /pembiayaan (Muhammad, 2005:42).

Pemberian

pembiayaan merupakan salah satu kegiatan bank dalam usahanya sebagai lembaga keuangan yang dipercaya untuk mendorong pertumbuhan ekonomi rakyat dengan berperan aktif dalam mengembangkan dunia usaha, meningkatkan kesempatan kerja, dan kesejahteraan ekonomi sesuai dengan nilai-nilai Islam.

Jenis pembiayaan pada dasarnya dapat dikelompokkan dalam beberapa aspek. Menurut Rivai dan Arviyan
(2010:718) pembiayaan berdasarkan tujuan penggunaanya dibagi menjadi tiga yaitu pembiayaan modal kerja, pembiayaan investasi dan pembiayaan konsumsi. Ismail (2011:113) menjelaskan perbedaan masing-masing jenis pembiayaan disebabkan karena adanya perbedaan tujuan penggunaanya. Sedangkan menurut Zulkifli (2007:63) menjelaskan bahwa perbedaan perlakuan antara pembiayaan konsumtif dan pembiayaan produktif terletak pada metode pendekatan analisisnya. Pembiayaan perbankan syariah di Indonesia berdasarkan tujuan penggunaan periode tahun 2009 sampai dengan tahun 2015 ditunjukkan pada

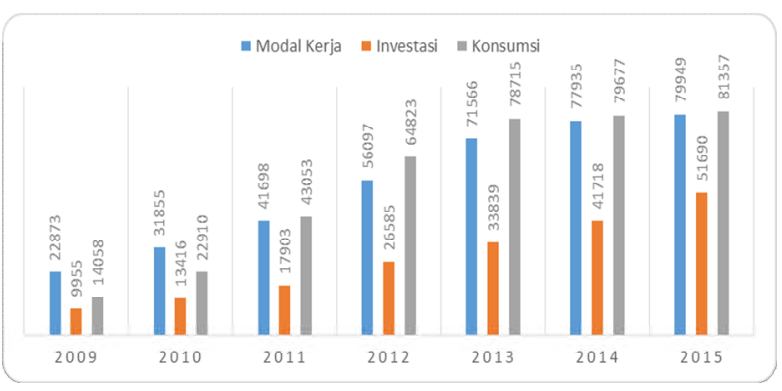

Sumber : Statistik Perbankan Syariah 2009-

2015, ojk.go.id (data telah diolah)

Gambar 1.

Grafik Perkembangan Jenis Pembiayaan Berdasarkan Penggunaan Bank Umum Syariah dan Unit Usaha Syariah Tahun 2009-2015

Dilihat dari grafik diatas, dari tahun ke tahun pembiayaan berdasarkan tujuan penggunaan terus meningkat. Meningkatnya pembiayaan ini disebabkan kebutuhan masyarakat yang terus bertambah dan kesadaran masyarakat untuk menggunakan jasa 
Legowati, et al/Jurnal Ekonomi Syariah Teori dan Terapan Vol. 3 No. 12 Desember 2016: 1006-1019; PENGARUH PEMBIAYAAN BERDASARKAN JENIS PENGGUNAAN TERHADAP NON PERFORMING FINANCING PADA BANK UMUM SYARIAH (BUS) DAN UNIT USAHA SYARIAH (UUS) DI INDONESIA PERIODE JANUARI 2009 - DESEMBER 2015

perbankan syariah dalam memenuhi kebutuhanya. Pada tahun 2011 sampai tahun 2015 pembiayaan yang tertinggi yaitu pembiayaan konsumsi kemudian diikuti oleh pembiayaan modal kerja sedangkan pembiayaan yang paling rendah adalah pembiayaan investasi. Rismayanti (2009) menjelaskan bahwa kredit konsumtif dominan karena kredit konsumtif menciptkan kenyamanan bagi pihak perbankan karena kerjanya relatif ringan, mudah dalam proses penagihan angsuran dan proses analisis kreditnya lebih mudah dibandingkan dengan kredit produktif (kredit modal kerja dan kredit investasi). Padahal pembiayaan konsumsi yang lebih besar dari produktif tentu tidak ideal karena peran perbankan syariah terhadap pertumbuhan ekonomi jadi berkurang.

Penyaluran pembiayaan oleh bank syariah tentunya dihadapkan dengan banyak risiko. Salah satu yang menjadi perhatian utama atas penyaluran pembiayaan adalah kemungkinan akan adanya risiko gagal bayar atau biasa disebut dengan Non Performing Financing (NPF). Non Performing Financing merupakan salah satu indikator utama untuk menunjukkan kesehatan bank. Oleh karena itu pihak perbankan syariah dalam menyalurkan pembiayaan kepada masyarakat harus benar-benar selektif dan menerapakan prinsip kehati-hatian. tingkat Non Performing Financing perbankan syariah dari tahun 2009 sampai tahun 2015 cenderung berfluktuatif.
Peningkatan NPF yang sangat tajam terjadi pada tahun 2013 yang awalnya sebesar 2,62\% kemudian pada tahun 2014 meningkat menjadi 4,33\%. Namun demikian nilai NPF masih tergolong normal karena masih dibawah persentase NPF $5 \%$.

Pembiayaan berdasarkan jenis penggunaan juga tidak lepas dari terjadinya pembiayaan non lancar. Tabel 1.1 menunjukan pembiayaan non lancar Bank Umum Syariah dan Unit Usaha Syariah berdasarkan jenis penggunaan tahun 2009 sampai tahun 2015 sebagai berikut:

Tabel 1.

Pembiayaan Non Lancar Bank Umum Syariah dan Unit Usaha Syariah Berdasarkan Jenis Penggunaan Tahun 2009-2015 (dalam satuan milyar)

\begin{tabular}{|c|r|r|r|r|r|l|l|}
\hline $\begin{array}{c}\text { Jenis } \\
\text { Penggunan }\end{array}$ & $\mathbf{2 0 0 9}$ & $\mathbf{2 0 1 0}$ & $\mathbf{2 0 1 1}$ & $\mathbf{2 0 1 2}$ & $\mathbf{2 0 1 3}$ & $\mathbf{2 0 1 4}$ & $\mathbf{2 0 1 5}$ \\
\hline Modal Kerja & 899 & 1.070 & 1.610 & 1.671 & 2.253 & 4.742 & 4.918 \\
\hline Investasi & 534 & 521 & 428 & 710 & 1.021 & 1.854 & 2.325 \\
\hline Konsumsi & 450 & 470 & 551 & 888 & 1554 & 2.035 & 2.005 \\
\hline Total & $\mathbf{1 . 8 8 2}$ & $\mathbf{2 . 0 6 1}$ & $\mathbf{2 . 5 8 8}$ & $\mathbf{3 . 2 6 9}$ & $\mathbf{4 . 8 2 8}$ & $\mathbf{8 . 6 3 2}$ & $\mathbf{9 2 4 8}$ \\
\hline
\end{tabular}

Sumber: Statistik Perbankan Syariah (SPS) 2009-2015, ojk.go.id (data telah diolah).

Tabel tersebut memperlihatkan bahwa pembiayaan non lancar berdasarkan jenis penggunaan meningkat setiap tahunya seiring dengan meningkatnya pembiayaan modal kerja, pembiayaan investasi dan pembiayaan konsumsi. Sehingga dapat disimpulkan bahwa meningkatnya pembiayaan berpengaruh terhadap pembiayaan non lancar yang berimbas pada tingkat NPF 
Legowati, et al/Jurnal Ekonomi Syariah Teori dan Terapan Vol. 3 No. 12 Desember 2016: 1006-1019; PENGARUH PEMBIAYAAN BERDASARKAN JENIS PENGGUNAAN TERHADAP NON PERFORMING FINANCING PADA BANK UMUM SYARIAH (BUS) DAN UNIT USAHA SYARIAH (UUS) DI INDONESIA PERIODE JANUARI 2009 - DESEMBER 2015

perbankan syariah. Hal ini diperkuat dengan penelitian terdahulu yang dilakukan oleh Arifin (2008) yang hasil penelitianya menunjukkan pembiayaan konsumtif dan produktif berpengaruh terhadap NPF. Hasil penelitian oleh Namun penelitian lainya yang dilakukan oleh Qadriyah (2002), menunjukan hasil pembiayaan produktif dan konsumtif tidak berpengaruh terhadap NPF.

Dari kedua penelitian tersebut memiliki hasil penelitian yang berbeda, sehingga masih menyisakan peluang untuk melakukan penelitian lebih lanjut untuk membuktikan pengaruh secara parsial dan simultan pembiayaan berdasarkan jenis penggunaan terhadap NPF. Di sisi lain jika dilihat kembali pada Gambar 1.1 peyaluran pembiayaan yang paling tinggi adalah pembiayaan konsumsi namun pada Tabel 1.1 menunjukan pembiayaan non lancar tertinggi adalah pembiayaan modal kerja dan pembiayaan investasi. Hal ini menarik untuk diteliti, oleh karena itu perlu dilakukan penelitian tentang pengaruh pembiayaan modal kerja, pembiayaan investasi dan pembiayaan konsumsi terhadap Non Performing Financing pada industri bank syariah di Indonesia periode Januari 2009 sampai dengan Desember 2015.

Rumusan masalah dalam penelitian ini adalah, apakah pembiayaan modal kerja, pembiayaan investasi dan pembiayaan konsumsi berpengaruh secara parsial dan simultan terhadap Non Performing Financing industri bank syariah di Indonesia?

Penelitian ini bertujuan untuk mengetahui pengaruh secara parsial dan simultan pembiayaan berdasarkan jenis penggunaan terhadap Non Performing Financing industri bank syariah di Indonesia.

\section{LANDASAN TEORI}

Muhammad (2004:1) menjelaskan bahwa bank syariah adalah bank yang beroperasi dengan tidak mengandalkan pada bunga, serta bank Islam adalah lembaga keuangan/perbankan yang operasional dan produknya dikembangkan berlandaskan pada AlQuran dan Hadits Nabi SAW.

Pembiayaan merupakan salah satu tugas pokok bank, yaitu pemberian fasilitas penyedian dana untuk memenuhi kebutuhan pihak-pihak yang merupakan defisit unit (Antonio, 2001:160). Pembiayaan menurut keperluanya, dibagi menjadi pembiayaan produktif dan pembiayaan konsumtif. Pembiayaan konsumtif adalah pembiayaan yang digunakan untuk memenuhi kebutuhan konsumsi, yang akan habis digunakan untuk memenuhi kebutuhan. Sedangkan pembiayaan produktif dibagi menjadi pembiayaan modal kerja dan pembiayaan investasi. Pembiayaan modal kerja adalah pembiayaan yang digunakan untuk memenuhi kebutuhan modal kerja yang biasanya habis dalam satu siklus usaha. Pembiayaan investasi adalah pembiayaan (berjangka 
Legowati, et al/Jurnal Ekonomi Syariah Teori dan Terapan Vol. 3 No. 12 Desember 2016: 1006-1019; PENGARUH PEMBIAYAAN BERDASARKAN JENIS PENGGUNAAN TERHADAP NON PERFORMING FINANCING PADA BANK UMUM SYARIAH (BUS) DAN UNIT USAHA SYARIAH (UUS) DI INDONESIA PERIODE JANUARI 2009 - DESEMBER 2015

menengah atau panjang) yang diberikan kepada usaha-usaha guna merehabilitasi, modernisasi, perluasan ataupun pendirian proyek baru (Rivai dan Arviyan, 2010:720).

Dalam penyaluran pembiayaan, bank syariah harus benar-benar selektif dan menjalankan prinsip kehati-hatian. Hal ini dilakukan agar bank dapat menekan atau meminimalkan resiko yang akan dihadapi, yaitu resiko pembiayaan bermasalah atau Non Performing Financing. Menurut Djamil (2012:66) Non Performing Financing adalah pembiayaan non lancar mulai dari kurang lancar sampai dengan macet yang dialami oleh nasabah.

Model penelitian yang digunakan dalam penelitian ini ditunjukkan pada gambar berikut:

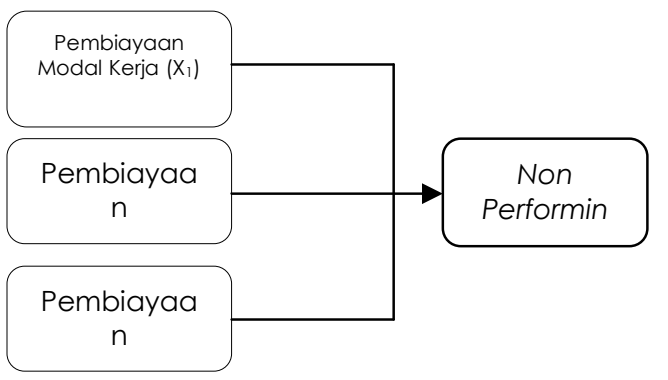

Gambar 2.

Model Analisis

Hipotesis yang digunakan dalam penelitian ini adalah:

1. Pembiayaan modal kerja berpengaruh signifikan terhadap Non Performing Financing perbankan syariah di Indonesia secara parsial

2. Pembiayaan investasi berpengaruh signifikan terhadap Non Performing Financing perbankan syariah di Indonesia secara parsial
3. Pembiayaan konsumsi berpengaruh signifikan terhadap Non Performing Financing perbankan syariah di Indonesia secara parsial

4. Pembiayaan modal kerja, pembiayaan investasi dan pembiayaan konsumsi berpengaruh signifikan terhadap Non Performing Financing perbankan syariah di Indonesia secara simultan.

\section{METODE PENELITIAN}

Pendekatan penelitian yang digunakan dalam penelitian ini adalah pendekatan kuantitatif. Penelitian dengan menggunakan pendekatan kuantitatif adalah penelitian yang menitikberatkan pada pengujian hipotesis, data yang digunakan harus terukur dan akan menghasilkan kesimpulan yang dapat digeneralisasikan. Pendekatan ini menggunakan metode (alat analisis) statistik inferensial (Anshori dan Iswati, 2009:155).

Dalam penelitian ini variabelvariabel yang digunakan sebagai berikut:

1. Variabel bebas (variabel independen) yang dibagi menjadi tiga variabel, yaitu: Pembiayaan Modal Kerja $\left(X_{1}\right)$, Pembiayaan Investasi $\left(X_{2}\right)$, Pembiayaan Konsumsi $\left(X_{3}\right)$.

2. Variabel terikat (variabel dependen) yaitu: Non Performing Financing pada BUS dan UUS.

\section{Definisi Operasional}

1. Non Performing Financing (NPF) adalah perbandingan jumlah 
Legowati, et al/Jurnal Ekonomi Syariah Teori dan Terapan Vol. 3 No. 12 Desember 2016: 1006-1019; PENGARUH PEMBIAYAAN BERDASARKAN JENIS PENGGUNAAN TERHADAP NON PERFORMING FINANCING PADA BANK UMUM SYARIAH (BUS) DAN UNIT USAHA SYARIAH (UUS) DI INDONESIA PERIODE JANUARI 2009 - DESEMBER 2015

pembiayaan

bermasalah

(pembiayaan dalam kualitas kurang lancar, diragukan dan macet) dengan total pembiayaan yang telah disalurkan. Data NPF dalam penelitian ini diperoleh dari laporan statistik perbankan syariah pada website resmi Otoritas Jasa Keuangan periode Januari 2009 hingga Desember 2015 dan diukur dengan menggunakan data nominal dalam milyar rupiah berskala rasio.

2. Pembiayaan Modal Kerja adalah pembiayaan yang diberikan oleh bank kepada nasabah untuk memenuhi kebutuhan modal kerja dalam jangka waktu pembiayaan maksimal 1 (satu) tahun. Data pembiayaan modal kerja dalam penelitian ini diperoleh dari laporan statistik perbankan syariah pada website resmi Otoritas Jasa Kevangan dengan periode Januari 2009 hingga Desember 2015 dan diukur dengan menggunakan data nominal dalam milyar rupiah berskala rasio.

3. Pembiayaan Investasi adalah pembiayaan yang bertujuan untuk memenuhi kebutuhan barangbarang modal (asset tetap) yang mempunyai nilai ekonomis lebih dari satu tahun. Data pembiayaan investasi diperoleh dari laporan statistik perbankan syariah pada website resmi Otoritas Jasa Keuangan dengan periode Januari 2009 hingga Desember 2015 dan diukur dengan menggunakan data nominal dalam milyar rupiah berskala rasio.

4. Pembiayaan Konsumsi adalah pembiayaan yang ditawarkan oleh bank umum syariah untuk membeli barang-barang untuk keperluan pribadi dan tidak untuk keperluan usaha. Data pembiayaan konsumsi diperoleh dari laporan statistik perbankan syariah pada website resmi Otoritas Jasa Kevangan dengan periode Januari 2009 hingga Desember 2015 dan data diukur dengan menggunakan data nominal dalam milyar rupiah berskala rasio.

Populasi dalam penelitian ini adalah industri bank syariah di Indonesia, proses pemilihan sampel dilakukan dengan purposive sampling. Sampel dalam penelitian ini adalah industri bank syariah yang diambil 84 bulan terakhir yaitu periode Januari 2009 sampai dengan periode Desember 2015.

Jenis data yang digunakan dalam penelitian ini adalah data sekunder yang diperoleh dari laporan statistik perbankan syariah yang dipublikasikan oleh Otoritas Jasa Keuangan.

Prosedur pengumpulan data dilakukan melalui studi pustaka dengan mengkaji buku-buku literatur, jurnal, makalah, dan sumber-sumber lainnya yang berkaitan dengan penelitian. Hal itu, dengan tujuan untuk memperoleh landasan teoritis secara komprehensif (mudah diterima atau dipahami) terkait industri perbankan syariah. 
Legowati, et al/Jurnal Ekonomi Syariah Teori dan Terapan Vol. 3 No. 12 Desember 2016: 1006-1019; PENGARUH PEMBIAYAAN BERDASARKAN JENIS PENGGUNAAN TERHADAP NON PERFORMING FINANCING PADA BANK UMUM SYARIAH (BUS) DAN UNIT USAHA SYARIAH (UUS) DI INDONESIA PERIODE JANUARI 2009 - DESEMBER 2015

Teknik analisis data yang digunakan dalam penelitian ini adalah analisis regresi linier berganda. Dalam melakukan analisis regresi linier berganda, metode ini mensyaratkan untuk melakukan uji asumsi klasik agar mendapatkan hasil regresi yang baik. Uji asumsi klasik terdiri dari uji normalitas, uji multikolinearitas, uji autokorelasi dan uji heteroskedastisitas.

Setelah uji asumsi klasik terpenuhi kemudian melakukan pengujian terhadap hipotesis yang diajukan dengan uji signifikansi variabel independen (X) terhadap variabel dependen (Y) baik secara parsial dengan uji statistic † (t-test) maupun secara simultan dengan menggunakan uji $\mathrm{F}$ (F-test) pada level 5\% $(a=0,05)$.

\section{HASIL DAN PEMBAHASAN}

Tabel 2.

Uji Multikolinearitas

\begin{tabular}{|c|c|c|l|}
\hline $\begin{array}{c}\text { Variabel } \\
\text { Bebas }\end{array}$ & $\begin{array}{c}\text { Nilai } \\
\text { VIF }\end{array}$ & $\begin{array}{c}\text { Nilai } \\
\text { Tolerance }\end{array}$ & Keterangan \\
\hline $\begin{array}{c}\text { Pembiayaan } \\
\text { Modal Kerja }\end{array}$ & 83,427 & 0,012 & $\begin{array}{l}\text { Terjadi } \\
\text { Multikolinearitas }\end{array}$ \\
\hline $\begin{array}{c}\text { Pembiayaan } \\
\text { Investasi }\end{array}$ & 34,244 & 0,029 & $\begin{array}{l}\text { Terjadi } \\
\text { Multikolinearitas }\end{array}$ \\
\hline $\begin{array}{c}\text { Pembiayaan } \\
\text { Konsumsi }\end{array}$ & 27,571 & 0,036 & $\begin{array}{l}\text { Terjadi } \\
\text { Multikolinearitas }\end{array}$ \\
\hline
\end{tabular}

Berdasarkan hasil tersebut nilai tolerance dari masing-masing variabel nilainya kurang dari 0,10 dan nilai VIF nya lebih dari 10 sehingga menunjukkan gejala multikolinearitas. Oleh karena itu perlu dilakukan penyembuhan dengan menggunakan metode first difference. Metode first difference dilakukan dengan membuat delta untuk setiap periode variabel yang artinya mengurangkan antara variabel periode $t$ dengan variabel sebelumnya (t-1). Berikut hasil uji multikolinearitas setelah melakukan metode first difference:

Tabel 3.

Uji Multikolinearitas

Setelah Penyembuhan dengan Metode First Difference

\begin{tabular}{|c|c|c|c|}
\hline $\begin{array}{c}\text { Variabel } \\
\text { Bebas }\end{array}$ & $\begin{array}{c}\text { Nilai } \\
\text { VIF }\end{array}$ & $\begin{array}{c}\text { Nilai } \\
\text { Tolerance }\end{array}$ & Keterangan \\
\hline $\begin{array}{c}\text { Pembiayaan } \\
\text { Modal Kerja }\end{array}$ & 1,394 & 0,717 & $\begin{array}{c}\text { Tidak Terjadi } \\
\text { Multikolinearitas }\end{array}$ \\
\hline $\begin{array}{c}\text { Pembiayaan } \\
\text { Investasi }\end{array}$ & 1,714 & 0,583 & $\begin{array}{c}\text { TidakTerjadi } \\
\text { Multikolinearitas }\end{array}$ \\
\hline $\begin{array}{c}\text { Pembiayaan } \\
\text { Konsumsi }\end{array}$ & 1,487 & 0,673 & $\begin{array}{c}\text { TidakTerjadi } \\
\text { Multikolinearitas }\end{array}$ \\
\hline
\end{tabular}

Berdasarkan Tabel 3 nilai VIF yang dibwah 10 dan nilai Tolerance dibawah satu menunjukkan bahwa variabel independen dalam penelitian ini sudah terbebas dan sembuh dari gejala multikolinearitas.

Tabel 4.

Uji Autokorelasi

\begin{tabular}{|c|c|c|c|}
\hline $\begin{array}{c}\text { Nilai } \\
\text { Durbin } \\
\text { Watson }\end{array}$ & $\begin{array}{c}\text { Nilai dU } \\
\text { dan Nilai } \\
\text { dL }\end{array}$ & 4- dU & Keterangan \\
\hline 0,769 & $\begin{array}{c}\mathrm{dU}=1,5723 \\
\mathrm{dL}=1,7199\end{array}$ & $\begin{array}{c}4-1,5723= \\
2,4277\end{array}$ & $\begin{array}{c}\text { Terjadi } \\
\text { Autokorelasi }\end{array}$ \\
\hline
\end{tabular}

Sumber: Hasil Pengolahan Data

Nilai Durbin-Watson sebesar 0,769 menunjukkan bahwa nilai tersebut tidak terdapat dalam rentang dU sampai 4-dU sehingga dapat dikatakan terjadi masalah autokorelasi. Terdapat beberapa cara untuk menyembuhkan masalah autokorelasi. Salah satunya dengan menggunakan metode first difference (Ghozali, 2013:122). Metode first difference yang digunakan untuk penyembuhan autokorelasi sama halnya dengan penyembuhan multikolinearitas yaitu dengan cara membuat delta untuk setiap periode variabel yang artinya 
Legowati, et al/Jurnal Ekonomi Syariah Teori dan Terapan Vol. 3 No. 12 Desember 2016: 1006-1019; PENGARUH PEMBIAYAAN BERDASARKAN JENIS PENGGUNAAN TERHADAP NON PERFORMING FINANCING PADA BANK UMUM SYARIAH (BUS) DAN UNIT USAHA SYARIAH (UUS) DI INDONESIA PERIODE JANUARI 2009 - DESEMBER 2015

mengurangkan antara variabel periode $\dagger$

dengan periode sebelumnya ( $\mathrm{t}-1)$.

Tabel 5.

Uji Autokorelasi

Setelah Penyembuhan dengan Metode Firs Difference

\begin{tabular}{|c|c|c|c|}
\hline $\begin{array}{c}\text { Nilai } \\
\text { Durbin- } \\
\text { Watson }\end{array}$ & $\begin{array}{c}\text { Nilai dU } \\
\text { dan Nilai } \\
\text { dL }\end{array}$ & 4- dU & Keterangan \\
\hline 2,145 & $\begin{array}{c}\mathrm{dU}=1,7187 \\
\mathrm{dL}=1,5693\end{array}$ & $\begin{array}{c}4-1,7187= \\
2,2813\end{array}$ & $\begin{array}{c}\text { Tidak Terjadi } \\
\text { Autokorelasi }\end{array}$ \\
\hline
\end{tabular}

Sumber: Hasil Pengolahan Data

Berdasarkan Tabel 5 diatas, pada taraf signifikan $5 \%$ menunjukkan bahwa nilai Durbin-Watson sebesar 2,145 berada dalam rentang dU sampai 4-dU sehingga dapat dikatakan penelitian ini sudah terbebas dari masalah autokorelasi.

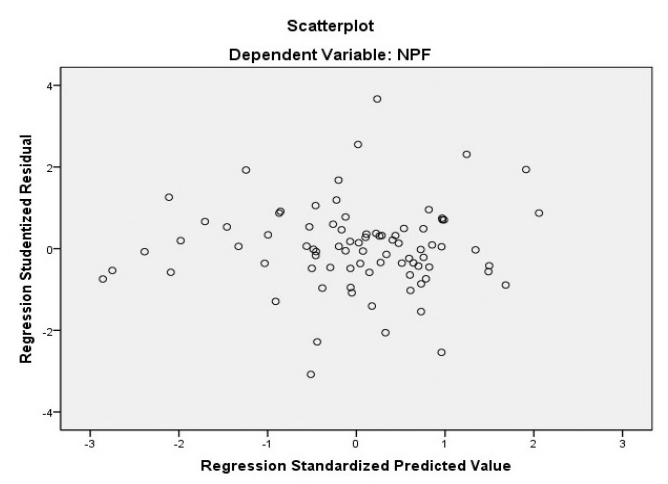

Gambar 3.

Uji Heteroskedastisitas

Dapat dilihat pada gambar 3 titiktitik menyebar secara acak, serta tersebar baik di atas maupun di bawah angka 0 pada sumbu Y. Maka dapat diambil kesimpulan bahwa tidak terdapat gejala heteroskedastisitas pada model regresi yang digunakan.

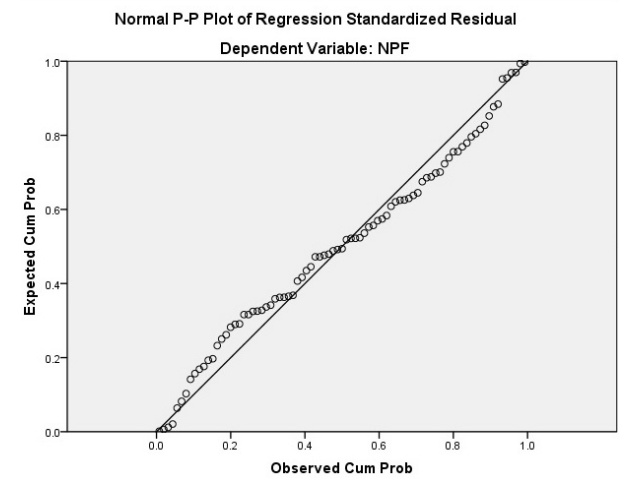

Gambar 4.

Uji Normalitas

Output grafik Normal P-Plot menunjukkan bahwa data (titik) menyebar di sekitar garis diagonal dan mengikuti arah garis diagonal. Menunjukkan pola distribusi normal maka model regresi memenuhi asumsi normalitas.

Tabel 6.

Koefisien Korelasi dan Koefisien Determinasi Multipel

Model Summaryb

\begin{tabular}{|l|c|r|r|r|r|}
\hline Model & $R$ & $\begin{array}{c}R \\
\text { Square }\end{array}$ & $\begin{array}{r}\text { Adjusted } \\
\text { R Square }\end{array}$ & $\begin{array}{c}\text { Std. Error } \\
\text { of the } \\
\text { Estimate }\end{array}$ & $\begin{array}{r}\text { Durbin- } \\
\text { Watson }\end{array}$ \\
\hline 1 & $.348 a$ & .121 & .087 & $3.457 E 11$ & 2.145 \\
\hline
\end{tabular}

a. Predictors: (Constant), PK, PMK, PI

b. Dependent Variable: NPF

Koefisien determinasi $\left(\mathrm{R}^{2}\right)$ sebesar 0,121 memberi pengertian bahwa variabel independen yg diteliti memiliki pengaruh kontribusi sebesar 12,1\% terhadap variabel NPF, sedangkan $87,9 \%$ lainnya dipengaruhi oleh faktor-faktor lain diluar variabel yg diteliti.

Tabel 7.

Analisis Regresi Linier Berganda

\begin{tabular}{|c|c|c|}
\hline Variabel & $\begin{array}{c}\text { Koefisien } \\
\text { Regresi }\end{array}$ & Keterangan \\
\hline Konstanta & $2,171 \mathrm{E} 11$ & $\begin{array}{c}\text { Merupakan } \\
\text { Intersep }\end{array}$ \\
\hline $\begin{array}{c}\text { Pembiayaan } \\
\text { Modal Kerja }\end{array}$ & $-0,0636$ & Bernilai Negatif \\
\hline $\begin{array}{c}\text { Pembiayaan } \\
\text { Investasi }\end{array}$ & $-0,1518$ & Bernilai Negatif \\
\hline $\begin{array}{c}\text { Pembiayaan } \\
\text { Konsumsi }\end{array}$ & $-0,0004$ & Bernilai Negatif \\
\hline
\end{tabular}


Legowati, et al/Jurnal Ekonomi Syariah Teori dan Terapan Vol. 3 No. 12 Desember 2016: 1006-1019; PENGARUH PEMBIAYAAN BERDASARKAN JENIS PENGGUNAAN TERHADAP NON PERFORMING FINANCING PADA BANK UMUM SYARIAH (BUS) DAN UNIT USAHA SYARIAH (UUS) DI INDONESIA PERIODE JANUARI 2009 - DESEMBER 2015

Dari Tabel 7 dapat dirumuskan persamaan model penelitian ini adalah:

$\mathrm{NPF}=2,171 \mathrm{E} 11-0,0636(\mathrm{PMK})-0,1518(\mathrm{PI})$ $-0,0004(P K)$

Penjelasan dari persamaan tersebut adalah sebagai berikut:

1. Konstanta sebesar 2,171E11 menunjukkan apabilai variabel Pembiayaan Modal Kerja, Pembiayaan Investasi dan Pembiayaan Konsumsi besarnya nol atau konstan, maka nilai Non Performing Financing (NPF) adalah sebesar 2,171E11.

2. Koefisien regresi pembiayaan modal kerja sebesar -0,0636 berarti apabila setiap kenaikan sebesar satu satuan dari pembiayaan modal kerja maka akan menurunkan Non Performing Financing sebesar 0,0636 dan sebaliknya setiap penurunan sebesar satu satuan dari pembiayaan modal kerja menyebabkan peningkatan Non Performing Financing sebesar 0,0636 dengan asumsi bahwa variabel yang lain adalah konstan.

3. Koefisien regresi pembiayaan investasi sebesar -0,1518 berarti apabila setiap kenaikan sebesar satu satuan dari pembiayaan investasi maka akan menurunkan Non Performing Financing sebesar 0,1518 dan sebaliknya setiap penurunan sebesar satu satuan dari pembiayaan investasi menyebabkan peningkatan Non Performing Financing sebesar
0,1518 dengan asumsi bahwa variabel yang lain adalah konstan.

4. Koefisien regresi pembiayaan konsumsi sebesar -0,0004 berarti apabila setiap kenaikan sebesar satu satuan dari pembiayaan konsumsi maka akan meningkatkan Non Performing Financing sebesar 0,0004 dan sebaliknya setiap penurunan sebesar satu satuan dari pembiayaan konsumsi menyebabkan penurunan Non Performing Financing sebesar 0,0004 dengan asumsi bahwa variabel yang lain adalah konstan.

Tabel 8.

Hasil Uji $F$

\begin{tabular}{|c|c|c|c|c|}
\hline$F_{\text {hitung }}$ & $\mathrm{F}_{\text {Tabel }}$ & Signifikansi & Interpretasi & Keterangan \\
\hline 3,620 & 2,72 & 0,017 & $\begin{array}{l}\text { Fitung }> \\
F_{\text {Tabel }}=\mathrm{H}_{0} \\
\text { ditolak } \\
3,620> \\
2,72 \\
\text { Signifikan } \\
<0,05=\mathrm{H}_{0} \\
\text { ditolak } \\
0,017< \\
0,05\end{array}$ & $\begin{array}{l}\mathrm{H}_{0} \text { ditolak } \\
\text { sehingga } \\
\text { variabel } \\
\text { independen } \\
\text { secara } \\
\text { simultan } \\
\text { berpengaruh } \\
\text { signifikan } \\
\text { terhadap } \\
\text { variabel } \\
\text { dependen }\end{array}$ \\
\hline
\end{tabular}

simultan di atas, didapatkan sig adalah < 0,05 yaitu sebesar 0,017 maka Ho ditolak dan dapat disimpulkan bahwa secara bersama-sama (simultan) pembiayaan modal kerja, pembiayaan investasi dan pembiayaan konsumsi berpengaruh signifikan terhadap NPF.

Tabel 9.

Hasil Uji †

\begin{tabular}{|c|c|c|c|}
\hline $\begin{array}{c}\text { Variabel } \\
\text { Independen }\end{array}$ & thitung & $\mathbf{t}_{\text {Tabel }}$ & Signifikansi \\
\hline $\begin{array}{c}\text { Pembiayaan } \\
\text { Modal Kerja }\end{array}$ & $-2,373$ & $-1,66$ & 0,020 \\
\hline $\begin{array}{c}\text { Pembiayaan } \\
\text { Investasi }\end{array}$ & $-2,827$ & $-1,66$ & 0,006 \\
\hline $\begin{array}{c}\text { Pembiayaan } \\
\text { Konsumsi }\end{array}$ & $-0,010$ & $-1,66$ & 0,992 \\
\hline
\end{tabular}


Legowati, et al/Jurnal Ekonomi Syariah Teori dan Terapan Vol. 3 No. 12 Desember 2016: 1006-1019; PENGARUH PEMBIAYAAN BERDASARKAN JENIS PENGGUNAAN TERHADAP NON PERFORMING FINANCING PADA BANK UMUM SYARIAH (BUS) DAN UNIT USAHA SYARIAH (UUS) DI INDONESIA PERIODE JANUARI 2009 - DESEMBER 2015

Setelah membandingkan trabel dan thitung serta melihat nilai signifikansinya dapat disimpulkan bahwa variabel pembiayaan modal kerja dan pembiayaan investasi berpengaruh secara parsial dan signifikan terhadap NPF. Sedangkan variabel pembiayaan konsumsi berpengaruh tidak signifkan terhadap NPF.

\section{PEMBAHASAN}

Dari hasil regresi analisis data secara statistic dalam penelitian ini menunjukkaan bahwa secara simultan pembiayaan modal kerja, pembiayaan investasi dan pembiayaan konsumsi memiliki pengaruh signifikan terhadap NPF perbankan syariah di Indonesia. Hal ini dibuktikan dengan nilai yang lebih kecil dari alfa $5 \%$ (sig 0,017 < a 0,05)

Secara parsial, pembiayaan modal kerja berpengaruh signifikan terhadap NPF. Hal ini dibuktikan dengan signifikansi sebesar 0,020 dimana nilai signifikansinya lebih kecil dari 0,05. Selanjutnya jika dilihat dari nilai negatif pada pada koefisien pembiayaan modal kerja memiliki arti bahwa pengaruh pembiayaan modal kerja berlawanan dengan NPF. Artinya semakin tinggi tingkat pembiayaan modal kerja yang disalurkan dari tahun ke tahun maka tingkat Non Performing Financing semakin menurun.

$$
\text { Menurut Antonio }
$$

penyebab utama timbulnya NPF adalah mudahnya bank memberikan pinjaman atau melakukan investasi karena terlalu dituntut untuk memanfaatkan likuiditas. Namun, tidak demikian dengan Bank Syariah hubungan berlawanan antara pembiayaan modal kerja dengan Non Performing Financing justru menunjukan bank syariah dalam menyalurkan pembiayaan modal kerja dan pembiayaan investasi sangat selektif memilih nasabah sesuai segmen dan target. Sehingga, perbankan bisa memastikan nasabah tersebut bisa membayar sesuai dengan ketentuan. Bank Syariah juga sangat berhati-hati dalam menentukan besarnya porsi skim pembiayaan maupun dalam melakukan analisa pembiayaan, serta selalu berusaha menerapkan kebijakankebijakan yang sesuai dengan prinsipprinsip syariat Islam dalam segala kegiatan operasionalnya sehingga terjadinya pembiayaan macet sangat kecil.

Hubungan berlawanan antara pembiayaan modal kerja dengan Non Performing Financing juga bisa disebabkan bank syariah lebih suka menyalurkan pembiayaan modal kerja karena pembiayaan modal kerja merupakan pembiayaan jangka pendek dan digunakan untuk memenuhi kebutuhan modal kerja usaha seperti pembelian bahan baku, biaya upah, pembelian barang-barang dagangan dan kebutuhan dana lain yang sifatnya hanya digunakan selama satu tahun. Sehingga bank bisa mendapatkan keuntungan lebih besar dalam jangka 
Legowati, et al/Jurnal Ekonomi Syariah Teori dan Terapan Vol. 3 No. 12 Desember 2016: 1006-1019; PENGARUH PEMBIAYAAN BERDASARKAN JENIS PENGGUNAAN TERHADAP NON PERFORMING FINANCING PADA BANK UMUM SYARIAH (BUS) DAN UNIT USAHA SYARIAH (UUS) DI INDONESIA PERIODE JANUARI 2009 - DESEMBER 2015

waktu yang pendek. Walaupun dalam beberapa bulan terakhir ini pembiayaan modal kerja dalam penyaluranya menjadi urutan kedua setelah pembiayaan konsumsi.

Hasil penelitian ini sejalan dengan penelitian yang dilakukan oleh Arifin (2008) yang berjudul Pengaruh Jenis Produk, Pembiayaan dan Segmentasi Pembiayaan Terhadap Non Performing Financing Pada Bank Syariah. Dalam penelitian tersebut menjelaskan bahwa variabel pembiayaan modal kerja berpengaruh terhadap NPF.

Hasil analisis uji $\dagger$ menunjukkan bahwa pembiayaan investasi dengan tstat $-2,827$ dan tingkat signifikan sebesar 0,006 memiliki pengaruh negatif yang signifikan terhadap NPF.

Pembiayaan investasi biasanya diberikan dalam jangka waktu panjang yaitu lebih dari satu tahun dan digunakan untuk pembelian barang-barang modal (aset tetap), misalnya untuk pendirian perusahaan baru, modernisasi mesin dan peralatan, pembelian alat angkutan yang digunakan untuk kelancaran usaha serta perluasan usaha. Walaupun dalam penyaluranya pembiayaan investasi merupakan penyaluran pembiayaan terendah menurut Qadriyah (2002) dan Meitasari (2014) pembiayaan investasi memiliki risiko yang paling besar jika dibandingkan kredit modal kerja dan kredit konsumsi karena kredit investasi digunakan untuk tujuan pembelian barang-barang produksi jangka panjang dan dalam nominal besar maka risiko yang dihadapi dalam pembiayaan investasi pun lebih tinggi karena didasarkan pada hasil yang diperoleh dari proses produksi yang dilakukan.

Pada periode penelitian ini pengaruh negatif pembiayaan investasi terhadap NPF menunjukkan bahwa manajemen perbankan syariah yang berjalan dengan baik berasaskan prinsip syariah dan prinsip kehati-hatian. Berdasarkan penjelasan pasal 2 UndangUndang Perbankan Syariah yang dimaksud dengan prinsip kehati-hatian adalah pedoman pengelolaan bank yang wajib dianut guna mewujudkan perbankan yang sehat, kuat dan efisien.

Untuk menghindari terjadinya pembiayaan macet, di dalam bank syariah terdapat kegiatan pembinaan dan regular monitoring yaitu dengan monitoring aktif dan monitoring pasif. Sehingga munculnya pembiayaan macetnya kecil. Monitoring aktif adalah mengunjungi nasabah secara regular, memantau laporan keuangan secara rutin dan memberikan laporan kunjungan nasabah/call report kepada komite pembiayaan/supervisor. Sedangkan monitoring pasif yaitu memonitoring pembayaran kewajiban nasabah kepada bank syariah setiap akhir bulan. Bersamaan pula diberikan pembinaan dengan memberikan saran, informasi maupun pembinaan teknis yang bertujuan untuk menghindari pembiayaan 
Legowati, et al/Jurnal Ekonomi Syariah Teori dan Terapan Vol. 3 No. 12 Desember 2016: 1006-1019; PENGARUH PEMBIAYAAN BERDASARKAN JENIS PENGGUNAAN TERHADAP NON PERFORMING FINANCING PADA BANK UMUM SYARIAH (BUS) DAN UNIT USAHA SYARIAH (UUS) DI INDONESIA PERIODE JANUARI 2009 - DESEMBER 2015

bermasalah. Hasil penelitian ini mendukung penelitian Arifin (2008).

Hasil analisis uji $t$ menunjukkan bahwa pembiayaan konsumsi dengan tstat $-0,010$ dan tingkat signifikan sebesar 0,992 memiliki pengaruh negatif dan tidak signifikan terhadap NPF. Hasil penelitian ini sesuai dengan penelitian Qadriyah (2002).

Tidak adanya pengaruh signifikan pembiayaan konsumsi terhadap NPF disebabkan pembiayaan konsumsi yang diberikan kepada nasabah adalah untuk kepentingan pribadi biasanya untuk memenuhi kebutuhan sehari-hari sehingga permintaanya cukup stabil. Pembiayaan konsumsi juga biasanya digunakan oleh masyarakat untuk pemilikan rumah, rata-rata orang yang akan membeli rumah merupakan orang yang memiliki pendapatan tetap yang tidak terpengaruh pada naik turunya kondisi perekonomian. Hal inilah yang menyebabkan pembiayaan konsumsi berpengaruh tidak signifikan terhadap Non Performing Financing. Hasil ini dapat diartikan bahwa tinggi atau rendahnya penyaluran pembiayaan konsumsi tidak terlalu berpengaruh pada NPF bank syariah.

\section{SIMPULAN}

Simpulan yang dapat diambil dari hasil penelitian adalah sebagai berikut:

1. Pembiayaan Modal Kerja secara parsial memiliki pengaruh yang signifikan terhadap Non Performing Financing dengan koefisien regresi sebesar -0,0636. Hal tersebut menunjukkan bahwa setiap terjadi kenaikan sebesar satu satuan pada pembiayaan modal kerja maka akan meurunkan tingkat Non Performing Financing sebesar 0,0636 satuan.

2. Pembiayaan Investasi secara parsial memiliki pengaruh yang signifikan terhadap Non Performing Financing dengan koefisien regresi sebesar 0,1518. Hal tersebut menunjukkan bahwa setiap terjadi kenaikan sebesar satu satuan pada pembiayaan investasi maka akan meurunkan tingkat Non Performing Financing sebesar 0,1518 satuan.

3. Pembiayaan konsumsi memiliki pengaruh yang tidak signifikan terhadap Non Performing Financing industri bank syariah di Indonesia.

4. Pembiayaan modal kerja, pembiayaan investasi dan pembiayaan konsumsi secara simultan memiliki pengaruh terhadap Non Performing Financing pada industri bank syariah di Indonesia dengan tingkat sig 0,017 pada taraf nyata 0,05.

\section{DAFTAR PUSTAKA}

Algifari. 1997. Analisis Statistik Untuk Bisnis dengan Regresi, Korelasi, dan Nonparametrik. Yogyakarta: BPFEYOGYAKARTA

Al-Qur'an dan Terjemahannya.

Anshori, Muslich \& Sri Iswati. 2009. Buku Ajar Metodologi Penelitian Kuantitatif. Surabaya: Airlangga University Press

Antonio, Muhammad Syafi'i. 2001. Bank Syariah Dari Teori Ke Praktik. Jakarta: Gema Insani Press 
Legowati, et al/Jurnal Ekonomi Syariah Teori dan Terapan Vol. 3 No. 12 Desember 2016: 1006-1019; PENGARUH PEMBIAYAAN BERDASARKAN JENIS PENGGUNAAN TERHADAP NON PERFORMING FINANCING PADA BANK UMUM SYARIAH (BUS) DAN UNIT USAHA SYARIAH (UUS) DI INDONESIA PERIODE JANUARI 2009 - DESEMBER 2015

Arifin, Andy (2008) dalam skripsinya yang berjudul"Pengaruh Jenis Produk, Pembiayaan Dan Segmentasi Pembiayaan Terhadap Non Performing Financing Pada Bank Syariah". Skripsi dipublikasikan. Jakarta: UIN Syarif Hidayatullah

Arifin, Zainul. 2002. Dasar-Dasar Manajemen Perbankan. Jakarta : AlvaBet

2005. Dasar-Dasar Manajemen Bank Syariah. Jakarta: AlvaBet

2009. Dasar-Dasar Manajemen Bank Syariah. Jakarta: AlvaBet

Ascarya. 2007. Akad \& Produk Bank Syariah. Jakarta: RajaGrafindo Persada

Dendawijaya, Lukman. 2003. Manajemen Perbankan. Jakarta: Ghalia Indonesia.

Djamil, Faturrahman. 2012. Penyelesaian Pembiayaan Bermasalah di Bank Syariah. Jakarta: Sinar Grafika

Ghozali, Imam. 2006. Analisis Multivariat dengan Program SPSS. Semarang: Badan Penerbit Universitas Diponegoro

Multivariate 2013. Aplikasi Analisis 21 Update PLS Regresi. Semarang: Badan Penerbit Universitas Diponegoro

Huda, Nurul dan Mohammad Heykal. 2010. Lembaga Keuangan Islam. Jakarta: Kencana Prenada Media Group

Irfansyah, Mochammad (2007). dalam skripsinya yang berjudul "Pengaruh Jumlah Pembiayaan Yang Disalurkan Terhadap Tingkar Rasio Non Performing Financing Pada Bank DKI Syariah". Skripsi dipublikasikan. Jakarta : Fakultas Syariah dan Hukum UIN Syarif Hidayatullah

Ismail. 2011. Perbankan Syariah. Jakarta: Kencana Prenada Media Group.
Karim, Adiwarman A. 2013. Bank Islam Analisis Fiqih Dan Keuangan. Jakarta: PT RajaGrafindo Persada.

Karim, Adiwarman A. 2007. Ekonomi Makro Islami. Jakarta: PT RajaGrafindo Persada.

Kasmir. 2003. Bank dan Lembaga Kevangan Lainya. Jakarta. PT. Raja Grafindo Persada

Maharanie, Mega Ayu (2014). dalam skripsinya yang berjudul "Pengaruh Kecukupan Modal, Fungsi Intermediasi, Pembiayaan Bermasalah dan Biaya Operasional Terhadap Profitabilitas Industri Bank Syariah periode Januari 2010-Desember 2012". Skripsi dipublikasikan. Malang: Fakultas Ekonomi dan Bisnis Universitas Brawijaya.

Meitasari, Dinda Ayu. 2014. Analisis Pengaruh Kredit Konsumtif dan Produktif Terhadap Laba Bank Berdasarkan Kelompok Bank. Universitas Brawijaya Malang

Muhammad. 2002. Manajemen Bank Syariah. Yogyakarta : PP AMP YKPN 2004. Manajemen Dana Bank Syariah. Yogyakarta : Ekonisia 2005. Manajemen Dana Bank Syariah. Yogyakarta : Ekonisia

Otoritas Jasa Keuangan. 2009. Statistik Perbankan Syariah. 2016. Dalam www.ojk.go.id www.ojk.go.id

Perbankan Syariah. 2016. www.ojk.go.id

2012. Statistik Perbankan Syariah. 2016. Dalam www.ojk.go.id

2013. Statistik Perbankan Syariah. 2016. Dalam www.ojk.go.id 
Legowati, et al/Jurnal Ekonomi Syariah Teori dan Terapan Vol. 3 No. 12 Desember 2016: 1006-1019; PENGARUH PEMBIAYAAN BERDASARKAN JENIS PENGGUNAAN TERHADAP NON PERFORMING FINANCING PADA BANK UMUM SYARIAH (BUS) DAN UNIT USAHA SYARIAH (UUS) DI INDONESIA PERIODE JANUARI 2009 - DESEMBER 2015 $\begin{array}{ccc} & \text { 2014. } & \text { Statistik } \\ \text { Perbankan Syariah. } & 2016 . & \text { Dalam }\end{array}$ www.ojk.go.id Perbankan Syariah. 2016. Dalam www.ojk.go.id

PBI. 2011. Peraturan Bank Indonesia No. : 13/13/PBI/2011. Tentang Penilaian Kualitas Aktiva Produktif Bagi Bank Umum Syariah dan Unit Usaha Syariah. Bank Indonesia

PBI. 2006. Peraturan Bank Indonesia No.8/21/PBI/2006. Tentang Kualitas Penilaian Aktiva Bank Umum yang melaksanakan kegiatan usaha berdasar prinsip syariah. Bank Indonesia

Qadriyah, Nur Anisa. 2002. Pengaruh Jenis Produk Pembiayaan, Jenis Pembiayaan dan Jenis Sektor Ekonomi Pembiayaan Terhadap Non Performing Financing Pada Perbankan Syariah. Bandung : Jurnal Ekonomi UNPAD

Ramli, Seruni Ramadhanty dkk. 2012. Pengaruh Pemberian Kredit Berdasarkan Sektor Ekonomi dan Non Sektor Ekonomi Terhadap Return On Asset dan Non Performing Loan. Bandung: Universitas Islam Bandung

Rismayanti, Diah. 2009. Analisis Portofolio Kredit (Konsumtif dan Produktif) dan Pengaruhnya terhadap Laba. Bogor: Fakultas Ekonomi dan Manajemen IPB

Rivai, Veithzal dan Arviyan Arifin. 2010. Islamic Banking: Sebuah Teori, Konsep dan Aplikasi. Jakarta : PT Bumi Aksana

Rukmana, Linda Hardiani (2015).dalam skripsinya yang berjudul "Pengaruh Pembiayaan Modal Kerja, Pembiayaan Investasi dan Pembiayaan Konsumsi Terhadap Profitabilitas Industri Perbankan Syariah di Indonesia". Skripsi tidak dipublikasikan. Surabaya : Fakultas Ekonomi dan Bisnis Universitas Airlangga.

Santoso, Singgih. 2012. Aplikasi SPSS Pada Statistik Multivariat. Jakarta: PT Elex Media Komputindo
Solimun. 2002. Structural Equation Modelling, Lisrel dan Amos. Malang: Universitas Brawijaya

Sudarsono, Heri. 2004 Bank dan Lembaga Keuangan Syariah Deskripsi dan llustrasi. Yogyakarta : Ekonosia Kampus Fakultas Ekonomi Universitas Islam Indonesia

Sugiyono. 2010. Metode Penelitian Kuantitatif Kualitatif dan R\&D. Bandung: Alfabeta

Sumitro, Warkum. 2002. Asas-Asas Perbankan Islam dan LembagaLembaga Terkait BMl dan Takaful di Indonesia. Jakarta : Rajagrafindo Persada

Sunyoto, Danang. 2010. Uji KHI Kuadrat dan Regresi Untuk Penelitian. Yogyakarta: Graha Imu

Widarjono, Agus. 2010. Analisis Statistika Multivariat Terapan. Yogyakarta: UPP STIM YKPN

Zulkilfi, Sunarto. 2007. Panduan Praktis Transaksi Perbankan Syariah. Jakarta: Zikrul Hakim 